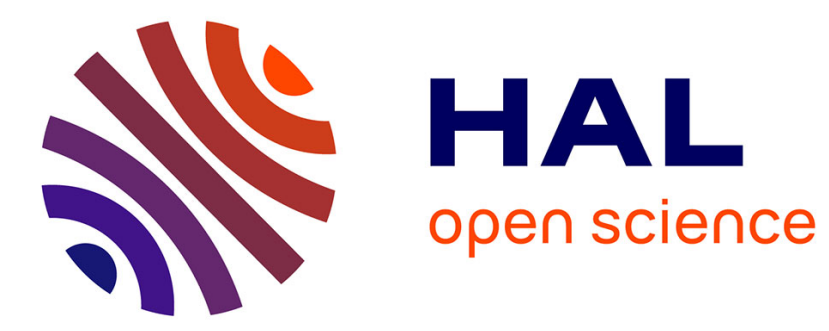

\title{
CONDUCTIVE POLYMERS AS ELECTRODE MATERIALS
}

M. Armand

\section{To cite this version:}

M. Armand. CONDUCTIVE POLYMERS AS ELECTRODE MATERIALS. Journal de Physique Colloques, 1983, 44 (C3), pp.C3-551-C3-557. 10.1051/jphyscol:19833110 . jpa-00222620

\section{HAL Id: jpa-00222620 https://hal.science/jpa-00222620}

Submitted on 1 Jan 1983

HAL is a multi-disciplinary open access archive for the deposit and dissemination of scientific research documents, whether they are published or not. The documents may come from teaching and research institutions in France or abroad, or from public or private research centers.
L'archive ouverte pluridisciplinaire HAL, est destinée au dépôt et à la diffusion de documents scientifiques de niveau recherche, publiés ou non, émanant des établissements d'enseignement et de recherche français ou étrangers, des laboratoires publics ou privés. 


\title{
CONDUCTIVE POLYMERS AS ELECTRODE MATERIALS
}

\author{
M. Armand
}

Laboratoire a'Energétique Electrochimique, CNRS LA 265, BP. 75, Domaine Universitaire, 38402 St-Martin-d'Hères, France

\begin{abstract}
Résumé - Le polyacétylène et ses homologues forment des composés d'insertion avec les anions et les cations. Cette propriété peut être mise à profit pour le stockage électrochimique de l'énergie. Cependant, tous les mécanismes électrochimiques ne sont pas parfaitement éclaircis, et les problèmes principaux sont évoqués ici.

Abstract - Polyacetylene and its related polymers are amphoteric insertion compounds accomodating both cations and anions. This property make them ideal candidates for electrochemical energy storage. However the electrochemistry of these compounds is not fully clarified and the main remaining problems are evoked here.
\end{abstract}

\section{INTRODUCTION}

In the field of energy storage, scientists have been almost kept at a stalemate with little improvements appearing in commercial devices despite a renewed interest in the past years.

A major breakthrough was expected with the concept of topochemical intercalation in layered compounds, where electrons and ions can be reversibly accomodated in a solid lattice [1] [2] [3]; it was even recognized that the best "classical" electrodes like $\mathrm{NiOOH}_{\mathrm{X}}$ work via an intercalation mechanism from aqueous solutions. However, enough unsolved problems stayed to delay the commercialization of high energy density batteries.

The "doping" of $(\mathrm{CH})_{\mathrm{X}}$ and related polymers (PP, PPP) is precisely an insertion phenomenon (the name insertion applying to any 1 to $3 \mathrm{D}$ compound, intercalation being mainly used for 2D [4]) in the sense that no strong lattice bonds are destroyed.

Interestingly $(\mathrm{CH})_{x}$ and $P P P$ are an amphoteric redox materials giving both anionic and cationic insertion compounds :

$$
\left(\begin{array}{l}
(\mathrm{CH})_{\mathrm{x}}+\mathrm{xyM}^{+}+\mathrm{xye}^{-} \rightleftharpoons\left(\mathrm{M}_{\mathrm{y}} \mathrm{CH}\right)_{\mathrm{x}} \\
(\mathrm{CH})_{\mathrm{x}}+\mathrm{xzx}^{-} \rightleftharpoons\left(\mathrm{CHX}_{\mathrm{z}}\right)_{\mathrm{x}}+\mathrm{xze}^{-}
\end{array}\right.
$$

Such dual behavior was previously only known for graphite, but the extreme reactivity of its intercalation compounds have precluded their practical use. First reports showed that $(\mathrm{CH})_{\mathrm{x}}$ insertion compounds occured under less drastic conditions.

The versatility of $(\mathrm{CH})_{x}$ doping can be used for various types [5] of electrochemical cells, as :

[1 $-\operatorname{metal}(M) /$ electrolyte $\left(M^{+} X^{-}\right) /\left(\operatorname{CHx}_{z^{\prime}}\right)+$ 
2

$\begin{array}{lll}-\operatorname{metal}(\mathrm{M}) / \text { electrolyte }\left(\mathrm{M}^{+} \mathrm{X}^{-}\right) /\left(\mathrm{M}_{\mathrm{y}} \mathrm{CH}\right) \mathrm{x} & + \\ -\left(\mathrm{M}_{\mathrm{y}} \mathrm{CH}\right)_{\mathrm{x}} / & / \text { electrolyte }\left(\mathrm{M}^{+} \mathrm{X}^{-}\right) /\left(\mathrm{CHX}_{\mathrm{z}}\right)_{\mathrm{x}}+\end{array}$

The most studied metal is lithium, and the counter-anion has to be non-oxidizable, non-nucleophilic, like $\mathrm{ClO}_{4}^{-}, \mathrm{PF}_{6}^{-}, \mathrm{AsF}_{6}{ }^{-}$. Such systems can be used for secondary batteries only if the cell components maintain their functions and integrity with cycling, implying :

- total reversibility of the reaction : for a lifetime of $\approx 1000$ cycles a $>99.9 \%$ turnaround efficiency/cycles is needed with an inert solvent in the electrolyte,

- high doping levels to achieve respectable energy densities. This problem has been discussed elsewhere [6],

- fast kinetics : a practical battery need to be charged/discharged in $\simeq 2$ hours ( $C / 2$ rate).

Though extensive electrochemical studies of $(\mathrm{CH})_{\mathrm{X}}$ doping are only in progress, the already known results confronted with the cumulated information from intercalation compounds electrochemistry allow to draw some partial conclusions or predictions. The difficult points will be addressed separately here.

\section{THE NEGATIVE ELECTRODE}

Type I and II celis use a pure metal negative electrode, lithium being specially attractive for its lightweight and its apparent stability in contact with many organic solvents. Indeed, a few hundreds of cycles for an oversized lithium electrode can be achieved in laboratory tests, but short circuits due to dendritic growth of the negative electrode remain the principal failure mode even for the technologically advanced systems, like the $\mathrm{Li}^{\mathrm{TiS}} 2$ cell [7].

This problem is in fact characteristic of any metal/metal ion electrochemical process (electrode of the first kind), as the flat interface morphology is inherently unstable toward any local fluctuation of the current density. Though levelling additives allow the formation of specular deposits, their effect fades with cycling. Lithium and zinc plating are yet two unsuccessful examples of electrodes of the first kind in battery technology. In the case of the alkali metal, the formation of a passivation layer in contact with the electrolyte enhances the nucleation of dendrites through cracks in the surface film.
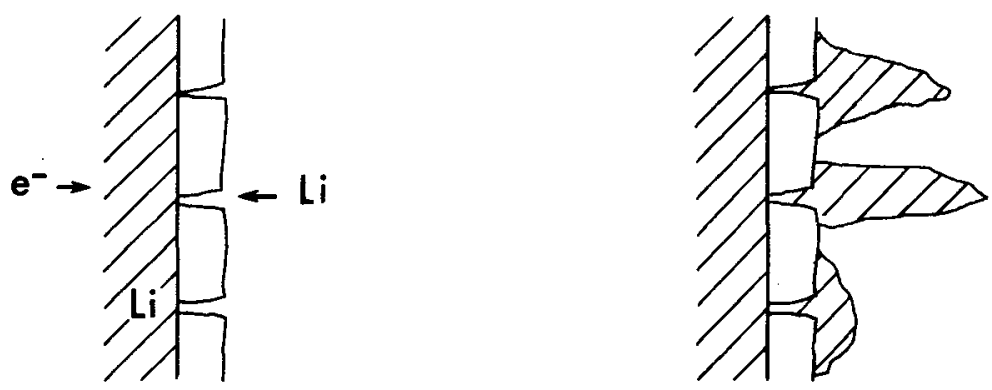

Fig. (1) Lithium dendritic growth on plating through a passivation layer. 
The only possibility to avoid an instable interface is to use instead of the metal itself an alloy or an intercalation compound with high chemical potential of the alkali metal (as ions and electrons can diffuse in the bulk of the electrode without accumulating at unit activity at the interface). For the purpose, 1ithium-aluminum, 1ithium-silicon alloys and graphite intercalates have been studied [8] [9] [10] [11] though in the latter case solvent co-intercalation is often observed (see below). In this respect, the type 3 cell discussed here, where a Li- $(\mathrm{CH})_{X}$ insertion compound is formed a the negative electrode also obviates the dendrite problem.

\section{SOLVENT STABILITY}

In any intercalation battery, the solvent has the sole role to dissociate the ion pairs $\mathrm{M}^{+} \mathrm{X}^{-}$and consists of polar molecules with solvating properties. Organic solvents are characterized by a voltage stability window beyond which parasitic reactions are observably fast. Yet, the problem of solvent impurities in the $100 \mathrm{ppm}$ level and of slow electrochemical degradation is often overlooked. $(\mathrm{CH}) \mathrm{x}$ doping creates either a carbocation or a carbanion, and in a simple approach, it is logical to consider that at the potentials needed for such reactions, some solvent decomposition may take place, since the bonds energies in both $(\mathrm{CH})_{\mathrm{x}}$ and an organic solvent are of roughly equal stability; the extensively conjugated electronic system in graphite being even more difficult to perturbate.

This problem we predicted already [6] is appearing as a major snag for a11-organic batteries.

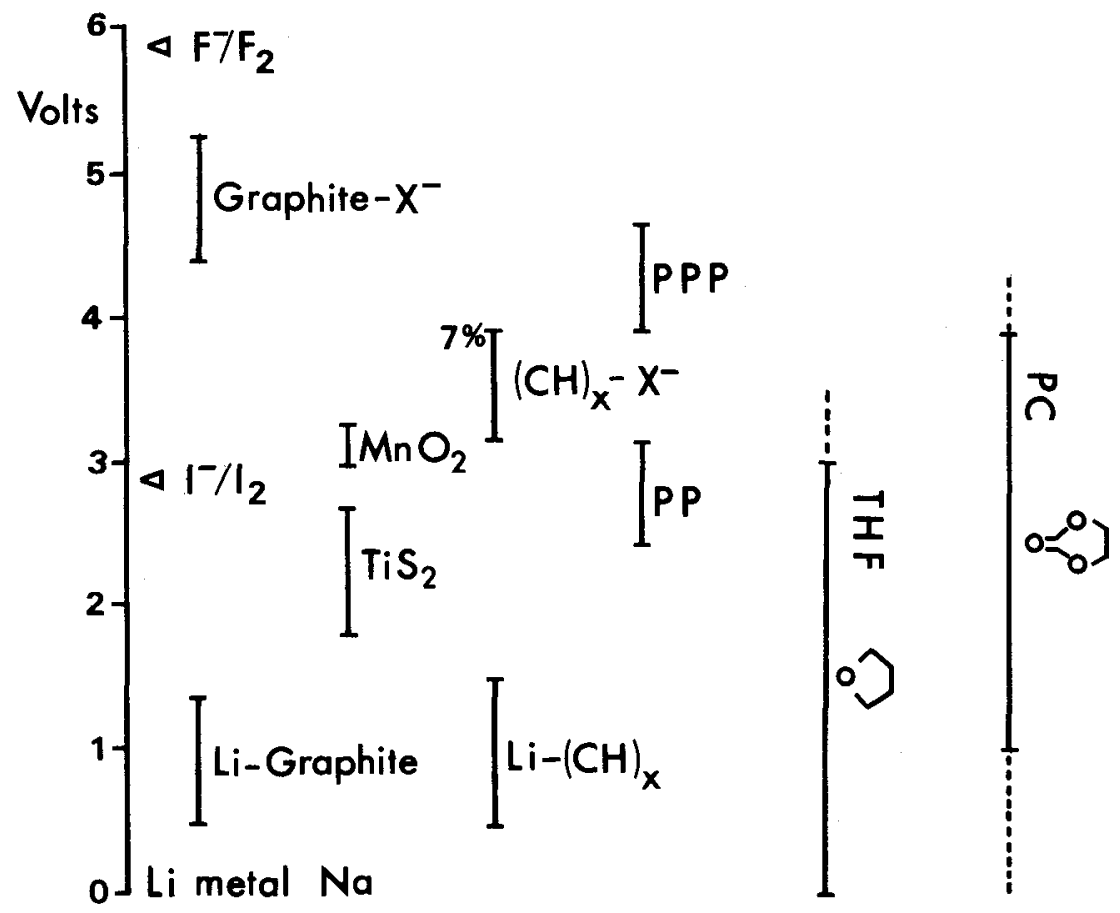

Fig. (2) Scale of insertion potentials for various electrode materials - stability widow of THF and PC. 
In figure (2) we have placed the potential domains for some intercalation electrodes inorganic or organic. On the same scale, the known stability domain for two major solvents, THF and PC is also shown. As apparent on this diagram, $\mathrm{p}$ type doping (anion insertion) takes place at a potential close to the anodic limit of one solvent, propylene carbonate (PC), and already beyond that of cyclic ethers, and faradaic efficiencies in the range $95-98 \%$ are reported [12].

PC with electron-withdrawing substituents $(\mathrm{C}=0)$ is more resistant to oxidation than simple ethers like THF and dioxolane who tend to polymerize via a radical cation, according to :

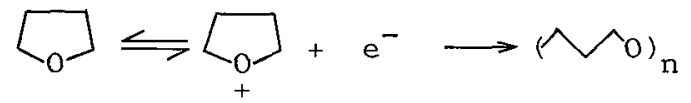

Reciprocally, the propylene carbonate is reduced at relatively positive potentials $\left(+1 \mathrm{~V} / \mathrm{Li}: \mathrm{Li}^{+}\right)$according to :

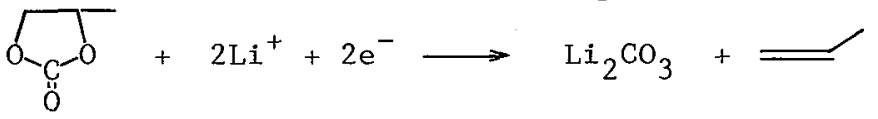

Thus PC cannot be used for $n$ doping of $(\mathrm{CH})_{x}$ nor graphite while THF can. On the other hand, oxidation of $(\mathrm{CH}) \times$ in the presence of cyclic ethers results in extensive polymerization of the solvent.

Another difficulty encountered with liquid electrolytes is the co-inter calation of the organic molecule in the lattice. This problem was found to exist only for low $D$ compounds, when no steric hindrance prevents the invasion of the solid by large solvent molecules. In the case of cation insertion, the aprotic electrolytes strongly solvates the polarizing cation $\left(\mathrm{Li}^{+}\right)$, and therefore the cation tends to be incorporated with its coordination shell. Graphite was known to form only ternary compounds upon electrochemical intercalation until solvent-free polymer electrolytes were used [11].

There is now definite evidence that irreversible solvent uptake plays a major role in $n$ doping of $(\mathrm{CH})_{X}$ in the case of $\mathrm{Li}^{+}$ion insertion $[13], \mathrm{Na}^{+}$and $\mathrm{K}^{+}$yield compounds with loosely bound solvent that can be removed in vaccum. This is corroborated by the observation that only the heavier alkali metals give ordered X-rays structures [14].

Though graphite was shown to also incorporate solvent molecules during anion intercalation [15], the mechanism probably does not involve solvation, but the filling of the galleries left between the anion and the rigid carbon plane (spacer molecules). No solvent uptake has been reported for negative charges inserted within the more flexible $(\mathrm{CH})_{x}$ chains.

\section{KINETICS}

$(\mathrm{CH})_{\mathrm{X}}$ used in films is made of $\simeq 100 \AA$ fibrils creating a felt-like network. Diffusion experiments from chemical or electrochemical reactions indicate a very 1 ow diffusion coefficient, especially for anions $\mathrm{D} \simeq 10^{-15^{2}}-10^{-18} \mathrm{~cm}^{2} / \mathrm{s}$ [16] [17]. Such surprising value for a compound with reduced dimensionality (i.e. $\mathrm{TiS}_{2} \mathrm{D}=10^{-9} \mathrm{~cm}^{2} / \mathrm{s}$ ) can only be compared with for instance carbon in steel, an admittedly slow process [18]. The determination of $D \simeq 10^{-14} \mathrm{~cm}^{2} / \mathrm{s}$ for unsolvated $\mathrm{L} i$ in $(\mathrm{CH})_{\mathrm{x}}\left[19 \mathrm{j}\right.$ was made at $83^{\circ}$ and the motion in thus thermally activated. Two explanations can be put forward to justify the slow process : existence of an appreciable covalent character in the $C-X(M)$ bonds ; but also, the formation of stages (i.e. discrete compositions) as evidenced 
now in $(\mathrm{CH}) \mathrm{x}$ chemistry [20] [14] explains slow kinetics, as the dopantrich domains require cooperative reorganization to diffuse in the solid (Fig. 3).

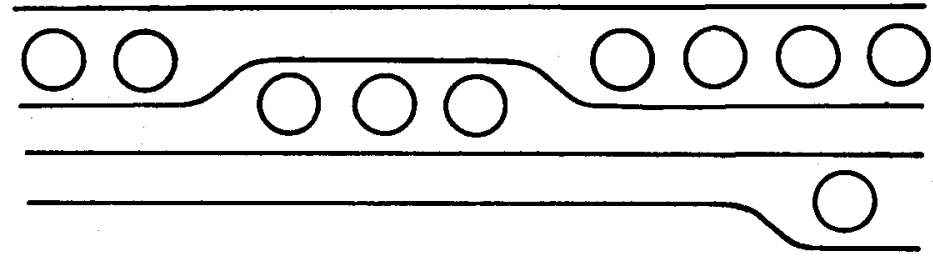

Fig. (3) Formation of encapsulated domains in staged insertion compounds.

The diffusion length being extremely short, $(\mathrm{CH})_{\mathrm{x}}$ electrodes behave reasonnably well when soaked with a liquid electrolyte.

The mathematical treatment of such porous electrode is extremely complex, and a simple model is that of a Warburg impedance (Fig. 4), where the pseudo-electrochemical capacitances of the electrode material are connected through the resistance of the electrolyte.

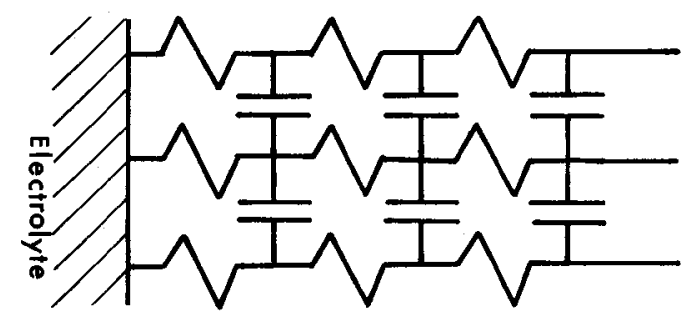

Fig. (4) Schematic Warburg equivalent circuit for a porous electrode.

In the case when $\mathrm{D} / \mathrm{a}^{2}>\mathrm{t}$

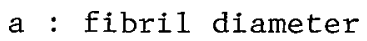

$t$ : (dis)charge time

the electrode behaves as having an apparent diffusion coefficient [22]

$$
\begin{aligned}
\overline{\mathrm{D}}=\sigma \cdot \frac{1}{\mathrm{~F}} & \cdot \frac{\partial \mathrm{E}}{\partial \mathrm{C}} \\
\sigma & =\text { conductivity of the electrolyte } \\
\frac{\partial \mathrm{E}}{\partial \mathrm{C}} & =\text { derivative of the voltage-composition curve }
\end{aligned}
$$

The voltage/composition curve is of the form [21]:

$$
\begin{gathered}
E=E_{0}-\frac{R T}{F} \cdot \ln \frac{C / C_{i}}{1-C / C_{i}}-\frac{R T}{F} \cdot \ln \frac{C / C_{e}}{1-C / C}+\text { (interaction term) } \\
C_{i}=\text { maximum concentration on ionic sites } \\
C_{e}=\text { maximum concentration on electronic sites }
\end{gathered}
$$


In the ideal case (interaction term $=0$ ), with classical electrolytes $\mathrm{LiClO}_{4}$ in PC or THF) D values of $\simeq 10^{-7} \mathrm{~cm}^{2} / \mathrm{s}$ can be observed, corresponding to a "fast" electrode material.

However, the proposed mechanism of a field enhanced diffusion [21] must be ruled out, as a global electroneutrality has to be obeyed inside the material; if we write the fluxes as a function of the electrochemical potentials :

$$
\left\{\begin{array}{r}
J_{i}=\frac{D_{i}}{R T} \cdot \frac{\partial}{\partial \text { (space) }}\left(\mu_{i}+F \Phi\right) \\
J_{e}=\frac{D_{e}}{R T} \cdot \frac{\partial}{\partial \text { (space) }}\left(\mu_{i}+F \Phi\right) \\
\Phi=\text { inner potential }
\end{array}\right.
$$

Since both electrons and ions are fermions an follow the same variation of chemical potential vs composition in the ideal case :

$$
\Delta \mu_{i}=R T \cdot \operatorname{In} \frac{C / C_{i}}{I-C / C_{i}} \simeq \Delta \mu_{e}=R T \cdot \ln \frac{C / C_{e}}{1-C / C_{e}} \quad C_{i}=C_{e}:
$$

equal number of sites

we have : $J=\frac{2}{1 / D_{i}+1 / D_{e}} \cdot \frac{1}{R T} \cdot \frac{\partial}{\partial(\text { space })}\left(u_{i}\right)$

Maximum enhancement occurs when $\mathrm{D}_{e}=\infty$, as the intrinsic ionic diffusivity is doubled. The electric fleld assisting the conduction in the electrolyte (unipolar conductor) cannot penetrate to a significant depth (i.e. the Helmoltz layer at $10 \AA$ ) inside the electrode due to the high density of mobile carriers of opposite charge (unlike dilute semiconductors). The Warburg model probably explains best the enhanced kinetics observed for $(\mathrm{CH})_{\mathrm{X}}$.

\section{CONCLUSIONS}

$(\mathrm{CH})_{\mathrm{x}}$ and its homologs have created great expectations for the electrochemists as amphoteric redox materials in the solid-state. As we have shown here, some problems have yet to be solved : on a practical basis, the finding of a perfectly inert solvent is a difficult but not impossible task, though no precise guideline can be used for such research.

Also, finding the exact answer to explain the strikingly low diffusion in $(\mathrm{CH}) \mathrm{x}$ is a challenge for physicists. If stages are present in $(\mathrm{CH})_{\mathrm{X}}$, the similarity of this compound with graphite will be even closer, but it is an obvious disadvantage for an electrode material, when diffusion implies an appreciable structure reorganization.

\section{REFERENCES}

[1] ROUXEL J., DANOT M., BICHON J., Bull.Soc. Chim. Fr. 11 (1971) 3930.

[2] ARMAND M.B., Fast Ion Transport in Solids, W. Van Gool Ed., North Holland, Amsterdam, (1973) 665. STEELE B.C.H., Ibid. (1973) 103.

[3] WHITTINGHAM M.S., J. Electrochem. Soc., 123 (1976) 315.

[4] "Materials for Advanced Batteries"; D.W. Murphy, J. Brodhead, B.C.H. Steele Ed., Plenum Press, New-York, (1980) 343. 
[5] NIGREY P.J., J. Electrochem. Soc., 128 (1981) 1651.

[6] ARMAND M., Polymères Electroactifs, Font-Romeu, P. Bernier, B. Payet Ed., C.N.R.S. Montpellier (1982).

[7] WHITTINGHAM M.S., Science, 192 (1976) 1126

[8] BESENHARD J.O., FRITZ H.P., Electrochimica Acta, 20 (1975) 513.

[9] RAO B.L.M., FRANCIS R.W., CHRISTOPHER H.A., J. Electrochem. Soc. 124 (1977) 1490 .

[10] SHARMA R.A., SEEFURTH R.N., Ibid, 124 (1981) 1763.

[11] YASAMI R., TOUZAIN Ph., International Meeting on Lithium Batteries, Rome, C.L.U.P. Ed. Milan, Abstract \# 23 (1982).

[12] FRYDRYCH D., HUG R., FARRINGTON G.G., Electrochem. Soc. Meeting, Extended Abstract, Montreal, (1982) 984 .

[13] FRANCOIS B., MATHIS C., This conference, Les Arcs.

[14] BAUGHMAN R.H., MURTHY N.S., SHACKLETTE L.W., MILLER G.G. and ECKHARDT H., This conference.

[15] CHENITE A., BILlAUd D., Carbon, 20 (1982) 121.

[16] RACHDI F., Thèse d'Université - Université de Montpellier (1981).

[17] KANETO K., MAXFIELD M., NAIRNS D.P., MacDIARMID A.G. and HEEGER A.J., J. Chem. Soc. Faraday Trans., 78 (1982) 3417.

[18] LORD A.E., BESHEVS D.N., Acta Met., 14 (1966) 1659.

[19] FOULETIER M., DEGOTT P., ARMAND M., This conference.

[20] WEGNER G., ENKELMANN V., MONKENBUSH M., WIENERS G., LIESER G., Ibid.

[21] KAUFMAN J.H., HEEgER A.J., MELE E.J., KANER R. and MacDIARMID A.G. Ibid.

[22] OWEN J.R., New Ways to Save Energy, 2nd Meeting on Advanced Batteries and Fuel Cells, EUR 8078 EN (1982) 54. 